Bangladesh J. Bot. 44(1): 143-146, 2015 (March)

\title{
RESIDUAL IMPACT OF WELLGROW FORMULATION AND NPK ON GROWTH AND YIELD OF WHEAT (TRITICUM AESTIVUM L.)
}

\author{
VS Meena, BR Maurya And RS Meena* \\ Department of Soil Science and Agricultural Chemistry, Institute of Agricultural Sciences, \\ Banaras Hindu University, Varanasi-221005, India
}

Key words: Organic Manure, Growth, Wheat, Wellgrow, Yield

\begin{abstract}
Effect of concentrate organic manure (wellgrow grain and wellgrow soil) and NPK improved the growth and yield of wheat. Significant improvement in terms of growth parameters like plant height, tillers, dry matter production and productive tillers with application of $120: 60: 60 \mathrm{NPK}+300 \mathrm{~kg}$ wellgrow soil/ha and at par with application of $120: 60: 60 \mathrm{NPK}+300 \mathrm{~kg}$ wellgrow grain/ha, treatment receiving 100\% NPK + $300 \mathrm{~kg}$ wellgrow soil/ha resulted maximum grain yield (4545 kg /ha). Treatment of $100 \% \mathrm{NPK}+300 \mathrm{~kg}$ wellgrow grain/ha maintained higher straw yield $(5715 \mathrm{~kg} / \mathrm{ha})$ and test weight $(44.10 \mathrm{~g})$ due to application of $100 \%$ NPK along with $200 \mathrm{~kg}$ wellgrow soil/ha whereas it was at par with application of 75 and $100 \%$ NPK with both levels of wellgrow formulation.
\end{abstract}

Wheat (Triticum aestivum L. Poaceae) is the world's leading cereal crop cultivated over an area of about 651 mha making it the third most-produced cereal after maize and rice. The integrated use of concentrate organic materials and inorganic fertilizers has received considerable attention in the past with a hope of meeting the farmer's economic need as well as maintaining eco-friendly conditions on long-term basis (Kumar et al. 2013). Regular use of a reasonable dose of organic manure, along with crop residue recycling, is known to cater the nutrient requirements of a low to medium intensity rice-wheat cropping system (Coventry et al. 2011). However, most of the long-term INM field research in South Asia pertains to rice-wheat system (Kumar and Dhar 2010). The integrated nutrient management helps to restore and sustain fertility and crop productivity together with economy and efficiency of fertilizer. Wellgrow is a plant product formulation in grain and powder forms produced by an Indian Tobacco Company (ITC). Hence, in the present investigation the effect of different doses of wellgrow formulation and NPK fertilizers on growth, yield and yield attributes of wheat was studied.

A field experiment was conducted during kharif seasons of 2009 to rabi season (2010) under the rice-wheat cropping system at the Agricultural Research Farm, Institute of Agricultural Sciences, Banaras Hindu University. Varanasi. Rice was sown in the first week of August and harvested during last week of November during 2009. After harvesting of rice, 'HUW 234' wheat variety was sown in last week of December and harvested during third week of April in 2010. Characterization of wellgrow soil and grain formulation are presented as organic carbon (\%) 20 25 and 18 - 20, total nitrogen (\%) 1.6 - 2.6 and $1.3-1.4, \mathrm{P}_{2} \mathrm{O}_{5}(\%) 0.25-1.2$ and 1.2, $\mathrm{K}_{2} \mathrm{O}(\%) 0.89$ - 1.47 and 1.4, C/N ratio $10-16: 1$ and 13 - 15:1, colour brown and black, moisture (\%) 9 - 10 and $8.2-8.4$, it act as eco-friendly.

*Author for correspondence: <rsmeenaagro@gmail.com>, Department of Agronomy, Institute of Agricultural Sciences, Banaras Hindu University, Varanasi-221005, India. 
Field experiment was laid out under randomized block design with three replications. Rice crop consisted of nine treatment of wellgrow formulation with NPK. $T_{1}: 100 \%$ NPK $(120: 60: 60$ $\mathrm{kg} / \mathrm{ha}$ ), $\mathrm{T}_{2}: 50 \% \mathrm{NPK}+300 \mathrm{~kg}$ wellgrow soil/ha, $\mathrm{T}_{3}: 50 \% \mathrm{NPK}+300 \mathrm{~kg}$ wellgrow grain/ha, $\mathrm{T}_{4}$ : $75 \% \mathrm{NPK}+200 \mathrm{~kg}$ wellgrow soil/ha, $\mathrm{T}_{5}: 75 \% \mathrm{NPK}+200 \mathrm{~kg}$ wellgrow grain/ha, $\mathrm{T}_{6}: 100 \% \mathrm{NPK}+$ $200 \mathrm{~kg}$ wellgrow soil/ha, $\mathrm{T}_{7}: 100 \% \mathrm{NPK}+200 \mathrm{~kg}$ wellgrow grain/ha, $\mathrm{T}_{8}: 100 \% \mathrm{NPK}+300 \mathrm{~kg}$ wellgrow soil/ha, $T_{9}: 100 \% \mathrm{NPK}+300 \mathrm{~kg}$ wellgrow grain/ha. Plot size was $4 \times 3.35 \mathrm{~m}^{2}$. one third of $\mathrm{N}$ and whole amount of $\mathrm{P}$ and $\mathrm{K}$ as per treatment were applied as basal and remaining amount of $\mathrm{N}$ was divided into 2 equal splits was applied at jointing and pre flowering stage. Various growth and yield parameters were observed at harvest following the standard procedure.

Data were assessed by Duncan's multiple range tests (Duncan 1955) with a probability ( $\mathrm{p}=$ 0.05 ). Least significant difference (LSD) between the mean values was evaluated by a one-way analysis of variance by using SPSS version 10.0.

Plant growth parameters of wheat i.e. plant height, tillers per hill and dry matter production per plant differed significantly (Table 1). Application of combined use of concentrate organic manure with inorganic fertilizer showed results in growth component than inorganic fertilizer alone. On overall results it was mentioned that the wellgrow soil with NPK was good for plant growth than the wellgrow grain with NPK.

Table 1. Residual effect of well grow formulation and NPK on growth and yield of wheat.

\begin{tabular}{lccccccc}
\hline Treatment & $\begin{array}{c}\text { Plant height } \\
(\mathrm{cm})\end{array}$ & $\begin{array}{c}\text { No. of } \\
\text { tillers/m }\end{array}$ & $\begin{array}{c}\text { Dry matter } \\
\text { production } \\
(\mathrm{g} / \mathrm{plant})\end{array}$ & $\begin{array}{c}\text { Test } \\
\text { weight } \\
(\mathrm{g})\end{array}$ & $\begin{array}{c}\text { Grain } \\
\text { yield } \\
(\mathrm{kg} / \mathrm{ha})\end{array}$ & $\begin{array}{c}\text { Straw } \\
\text { yield } \\
(\mathrm{kg} / \mathrm{ha})\end{array}$ & $\begin{array}{c}\text { Harvest } \\
\text { index } \\
(\%)\end{array}$ \\
\hline $\mathrm{T}_{1}$ & $87.7^{\mathrm{b}}$ & $77^{\mathrm{e}}$ & $267^{\mathrm{b}}$ & $43.7^{\mathrm{a}}$ & $3557^{\mathrm{e}}$ & $5041^{\mathrm{cd}}$ & $41.36^{\mathrm{b}}$ \\
$\mathrm{T}_{2}$ & $88.3^{\mathrm{ab}}$ & $80^{\mathrm{d}}$ & $262^{\mathrm{b}}$ & $44.1^{\mathrm{a}}$ & $3590^{\mathrm{e}}$ & $4917^{\mathrm{d}}$ & $42.23^{\mathrm{b}}$ \\
$\mathrm{T}_{3}$ & $89.3^{\mathrm{ab}}$ & $80^{\mathrm{d}}$ & $227^{\mathrm{c}}$ & $43.2^{\mathrm{a}}$ & $3854^{\mathrm{d}}$ & $5177^{\mathrm{bcd}}$ & $42.70^{\mathrm{b}}$ \\
$\mathrm{T}_{4}$ & $88.7^{\mathrm{ab}}$ & $84^{\mathrm{c}}$ & $248^{\mathrm{bc}}$ & $43.7^{\mathrm{a}}$ & $3926^{\mathrm{cd}}$ & $5237^{\mathrm{bcd}}$ & $42.84^{\mathrm{ab}}$ \\
$\mathrm{T}_{5}$ & $91.0^{\mathrm{ab}}$ & $85^{\mathrm{c}}$ & $233^{\mathrm{bc}}$ & $44.1^{\mathrm{a}}$ & $3903^{\mathrm{cd}}$ & $5376^{\mathrm{abc}}$ & $42.07^{\mathrm{b}}$ \\
$\mathrm{T}_{6}$ & $89.7^{\mathrm{ab}}$ & $85^{\mathrm{c}}$ & $325^{\mathrm{a}}$ & $43.7^{\mathrm{a}}$ & $4150^{\mathrm{bc}}$ & $5683^{\mathrm{a}}$ & $42.19^{\mathrm{b}}$ \\
$\mathrm{T}_{7}$ & $91.9^{\mathrm{a}}$ & $85^{\mathrm{bc}}$ & $314^{\mathrm{a}}$ & $44.1^{\mathrm{a}}$ & $4315^{\mathrm{ab}}$ & $5683^{\mathrm{a}}$ & $43.16^{\mathrm{ab}}$ \\
$\mathrm{T}_{8}$ & $90.5^{\mathrm{ab}}$ & $92^{\mathrm{a}}$ & $335^{\mathrm{a}}$ & $43.2^{\mathrm{a}}$ & $4545^{\mathrm{a}}$ & $5538^{\mathrm{ab}}$ & $45.09^{\mathrm{a}}$ \\
$\mathrm{T}_{9}$ & $91.0^{\mathrm{a}}$ & $87^{\mathrm{b}}$ & $334^{\mathrm{a}}$ & $43.2^{\mathrm{a}}$ & $4315^{\mathrm{ab}}$ & $5715^{\mathrm{a}}$ & $43.02^{\mathrm{ab}}$ \\
$\mathrm{LSD}(\mathrm{p}=0.05)$ & 3.082 & 2.05 & 33.38 & $N S$ & 257.10 & 383.15 & $\mathrm{NS}$ \\
\hline
\end{tabular}

*For each parameter, different lowercase letters within the same column indicate that treatment means are significantly different at $\mathrm{p}<0.05$ according to DMRT for separation of means.

In case of plant height treatment having $100 \%$ NPK $+300 \mathrm{~kg}$ wellgrow soil/ha exhibited tallest plants at harvest $\left(93.3 \mathrm{~cm}\right.$ ) than rest of the treatments. The treatment $\mathrm{T}_{8}$ produced significantly tallest plants than all the treatments but statistically at par with $T_{9}, T_{4}$ and $T_{5}$ (Sarwer et al. 2008). These results are supported by the findings of Abbas et al. (2012) who reported that the use of organic manures in combination with mineral fertilizers maximized the plant growth (Table 1). At harvest maximum number of tillers (92) was found with treatment $100 \%$ NPK +300 $\mathrm{kg}$ wellgrow soil/ha and increased $5.74 \%$ over $100 \% \mathrm{NPK}+300 \mathrm{~kg}$ wellgrow grain/ha. Tillers are an important, trait for grain production and are thereby an important aspect in yield. This is in agreement with the earlier findings of Singh et al. (2011).

In general, the dry matter production increased as the growth progressed. Maximum dry matter production observed at harvest with $100 \% \mathrm{NPK}+300 \mathrm{~kg}$ wellgrow soil/ha and it was statically at par with $\mathrm{T}_{9}$ and $\mathrm{T}_{6}$. The treatment of $\mathrm{T}_{8}$ showed 3 and $25 \%$ higher dry matter 
production over the treatment of $T_{6}$ and $T_{1}$, respectively. This may be due to the organic sources with inorganic fertilizer offer more balanced nutrition to the plants, especially micro nutrients which have caused better growth and tillering in plants there by dry matter production (Table 1). These finding is in close agreement with Kumar and Dhar (2010).

Test weight of wheat was maximum recorded with $\mathrm{T}_{7}(44.10 \mathrm{~g})$. The increase in grain yield components could be due to the fact that enhancing water holding capacity of soil by organic doses thus enhanced nutrient availability which improved nitrogen and other macro and micro elements absorption as well as enhancing the production and translocation of the dry matter content from source to sink. These results are supported by Kallesh et al. (2012). The varying nutrient management practices i.e. NPK levels and wellgrow formulations with residual effect significantly marked increase in the grain and straw yield of wheat. Maximum grain and straw yield (4545 and $5715 \mathrm{~kg} / \mathrm{ha}$ ) was recorded with $100 \% \mathrm{NPK}+300 \mathrm{~kg}$ wellgrow soil/ha and $100 \%$ $\mathrm{NPK}+300 \mathrm{~kg}$ wellgrow grain/ha and was approximately 28 and $13 \%$ higher over control, respectively. Almost similar grain yield (4315 kg/ha) was noticed with treatment $T_{7}$ and $T_{9}$ and straw yield (5683 kg/ha) with $\mathrm{T}_{6}$ and $\mathrm{T}_{7}$ treatment. The grain yield of wheat was significantly increased by combined effect of organic and inorganic sources of nutrients. Similar results were reported by Singh et al. (2011) and Chuan et al. (2013). It is evident from the data (Table 1) that harvest index of wheat was not affected significantly with different doses of NPK with wellgrow formulation of soil and grain. Harvest index ranged from 41.36 to $45.09 \%$. These findings confirmed those obtained by Rahimi (2012).

From the above investigation it is clear that use of wellgrow formulations of soil and grain with inorganic fertilizer to rice them a residual influence on growth and productivity of wheat. However, it was observed that the use of additional doses of concentrate organic manure with inorganic fertilizers significantly influenced growth and yield of wheat variety HUW-234. Among treatments, the application of wellgrow grain @300 kg/ha with 100\% NPK had significant effect on most of growth and yield contributing parameters of wheat. However, application of $100 \%$ $\mathrm{NPK}+300 \mathrm{~kg}$ wellgrow grain/ha in wheat was found statistically significant with most of the observed parameters.

\section{Acknowledgements}

The authors wish to acknowledge Indian Tobacco Company (ITC) for providing financial support to carry out this research work and authors are also thankful to the Head, Department of Soil Science and Agricultural Chemistry, Institute of Agricultural Sciences, BHU Varanasi, for providing the necessary facilities to conduct this research work.

\section{References}

Abbas G, Khattak JZK, Mir A, Ishaque M, Hussain M, Wahedi HM, Ahmed MS and Ullah A 2012. Effect of organic manures with recommended dose of NPK on the performance of wheat (Triticum aestivum L.). J. Anim. Plant Sci. 22(3): 683-687.

Chuan L, Ping H, Mirasol FP, Adrian MJ, Jiyun J, Xinpeng Xu, Shicheng Z, Shaojun Qiu, Wei Zhou 2013. Establishing a scientific basis for fertilizer recommendations for wheat in China: Yield response and agronomic efficiency. Field Crops Res. 140: 1-8.

Coventry DR, Poswal RS, Yadav A, Gupta RK, Gill SC, Chhokar RS, Kumar V, Sharma SK, Kumar A, Mehta A, Kleemann SGL and Cummins JA 2011. Effect of tillage and nutrient management on wheat productivity and quality in Haryana, India. Field Crops Res. 123: 234-240.

Duncan DM 1955. Multiple ranges and multiple F-tests. Biometric 11: 1-42. 
Kallesh DT, Singh GP, Singh UM, Ahlawat A and Sharma RK 2012. Genetic diversity analysis for moisture stress adaptive and quality traits in bread wheat (Triticum aestivum). Indian J. Agrl. Sci. 82(11): 978-84.

Kumar A and Dhar S 2010. Evaluation of organic and inorganic sources of nutrients in maize (Zea mays) and their residual effect on wheat (Triticum aestivum) under different fertility levels. Indian J. Agrl. Sci. 80(5): 364-71.

Kumar M, Bauddh K, Kumar S, Sainger M, Sainger PA Singh RP 2013. Increase in growth, productivity and nutritional status of wheat (Triticum aestivum L. cv. WH-711) and enrichment in soil fertility applied with organic matrix entrapped urea. J. Environ. Biol. 34: 1-9.

Rahimi A 2012. Effect of potassium and nitrogen on yield and yield components of dry land wheat in Boyerahmad Region of Iran. Annals Biol. Res. 3(7): 3274-3277.

Sarwar GH, Schmeisky N, Hussain S, Muhammad M, Ibrahim and Safdar E 2008. Improvement of soil physical and chemical properties with compost application in rice-wheat cropping system. Pak. J. Bot. 40(1): 275-282.

Singh CM, Sharma PK, Kishor P, Mishra AP, Singh AP, Verma R and Raha P 2011. Impact of integrated nutrient management on growth, yield and nutrient uptake by wheat (Triticum aestivum L.). Asian J Agrl Res. 5(1):76-82.

(Manuscript received on 22 July, 2013; revised on 3 August, 2014) 